\title{
A CV Study of Copper Complexation with Guanine Using Glassy Carbon Electrode in Aqueous Medium
}

\author{
Md. Sohel Rana, ${ }^{1}$ Mohammad Arifur Rahman, ${ }^{2}$ and A. M. Shafiqul Alam ${ }^{2}$ \\ ${ }^{1}$ Department of Chemistry, Chittagong University of Engineering \& Technology, Chittagong 4349, Bangladesh \\ ${ }^{2}$ Department of Chemistry, University of Dhaka, Dhaka 1000, Bangladesh
}

Correspondence should be addressed to Md. Sohel Rana; mdsohelrana.nbd@gmail.com and A. M. Shafiqul Alam; amsalam2010@gmail.com

Received 22 February 2014; Accepted 18 March 2014; Published 2 April 2014

Academic Editors: H. Karimi-Maleh and B. Lakard

Copyright (C) 2014 Md. Sohel Rana et al. This is an open access article distributed under the Creative Commons Attribution License, which permits unrestricted use, distribution, and reproduction in any medium, provided the original work is properly cited.

Voltammetric behaviors of Copper (II) nitrogen bearing nucleobases, such as Guanine $\left(\mathrm{C}_{5} \mathrm{H}_{4} \mathrm{~N}_{5} \mathrm{O}_{2}\right)$ was studied in electro analyzer using cyclic voltammetry (CV) on a Glassy Carbon Electrode. Assessment of the chemical and physical conditions that may favor optimum current enhancement was done by studying the effect of variation of concentration of metal and ligand ions, variation of scan rate, variation of step height, variation of $\mathrm{pH}$ values, and variation of supporting electrolyte as $\left(\mathrm{NH}_{4}\right)_{2} \mathrm{SO}_{4}, \mathrm{KCl}$, and NaCl. It was observed that Copper and Guanine forms a 1:2 ratio complex. The work reflects that increasing the concentration of either metal ion or ligand ion increases the corresponding current. Increasing the scan rate increases the corresponding current linearly with the square root of the scan rate. As the step height decreases the peaks become sharp. Anodic and cathodic current increases linearly with decreasing step height. For the complex mixture the complexation occurs maximum at a pH of 2.3-7.0 and is badly restricted in the slightly alkaline medium and the complexing order of the supporting electrolyte showed a trend as $\left(\mathrm{NH}_{4}\right)_{2} \mathrm{SO}_{4}>\mathrm{NaCl}>\mathrm{KCl}$.

\section{Introduction}

The complexation of organic compounds with selected metal ion has a wide variety of application in medicinal chemistry, surface chemistry, and analytical chemistry. Complexation of medicinal substances with ions influence the bioavailability of drugs in the body and the biological action that affects the stability of medicinal compounds since a large number of metals are taken into the body system either with drugs or in the form of diet. The complex formation has been suggested as one of the important mechanisms for certain drug action [1]. The metal chelating phenomena are used to reduce the toxic effect of drugs in human physiology. The studies of redox behavior biologically and biochemically important compound are gaining importance because such redox phenomena are close to natural processes occurring in human and living organism.

Toxic metals are generally more important than abundant metals, in terms of environmental pollution, because of their effects on living organisms. The study of trace metals toxicity on biological system $[2,3]$ indicates that an under supply would not yield steady growth and over supply would not, above the threshold level, generate toxicity with lethality at the end. At least twenty metals are known to be toxic and half of these including $\mathrm{As}, \mathrm{Cd}, \mathrm{Cr}, \mathrm{Cu}, \mathrm{Pb}, \mathrm{Ni}, \mathrm{Ag}$, Se, $\mathrm{Mn}$, and $\mathrm{Zn}$ are released into the environment in sufficient quantities to pose a risk to human health [4-6].

Copper (II) ions $\left(\mathrm{Cu}^{2+}\right)$ are soluble in water, where they function at low concentration as bacteriostatic substances, fungicides, and wood preservatives. In sufficient amounts, copper salts can be poisonous to higher organisms as well. However, despite universal toxicity at high concentrations, the $\mathrm{Cu}^{2+}$ ion at lower concentrations is an essential trace nutrient to all higher plant and animal life. In animals, including humans, it is found widely in tissues, with concentration in liver, muscle, and bone. It functions as a co-factor in various enzymes and in copper-based pigments.

Nucleobases are nitrogen-containing biological compounds found within DNA, RNA, nucleotides, and nucleosides. They are also termed as nitrogenous bases or simply 
<smiles>Nc1nc2[nH]cnc2c(=O)[nH]1</smiles>

SCHeme 1: Chemical structure of guanine.

bases due to their ability to form base-pairs and to stack upon one another leading directly to the helical structure of DNA and RNA. The primary Nucleobases bases are cytosine, guanine (Scheme 1), adenine (DNA and RNA), thymine (DNA), and uracil (RNA), abbreviated as C, G, A, T, and U, respectively.

In DNA, guanine is paired with cytosine. With the formula $\mathrm{C}_{5} \mathrm{H}_{5} \mathrm{~N}_{5} \mathrm{O}$, guanine is a derivative of purine, consisting of a fused pyrimidine-imidazole ring system with conjugated double bonds. Being unsaturated, the bicyclic molecule is planar. Guanine has the C- 6 carbonyl group that acts as the hydrogen bond acceptor, while a group at N-1 and the amino group at C-2 act as the hydrogen bond donors.

Metals in the ionic forms have essential catalytic physiological functions to perform in living systems, including human [7]. Excess metal ions in human system can damage specific organs. Free metal ions are more toxic than metal chelates. Thus, the chelating agents are used in medicine for the formation of soluble easily extractable metal chelates by sequestering metal ions in the circulation of blood. In the present research guanine have been used to form complex with the free metal ion and to study how it can be made nontoxic in the body. Since chelation is the elimination of all the binding sites in the metal ion and as such chemical bonds to essential enzymes cannot be formed, lowering of toxicity by chelation of metal ions is ensured $[8,9]$.

Guanine is a critical component of DNA; it has extra duties to perform in the cell, including defying the characteristics of the living body. In other words, they function as character determiner. Interestingly, guanine functions by binding to phosphate group and form guanosine and takes part in cell mechanism with thymine. This later involves numerous enzymatic reactions necessary for sustaining life and protecting the cell from toxins, either that produced by our cells or carcinogenic in our environment.

Thus researches on synthesis and properties of various metal-amino acid complexes are important from the view point of chemistry, bio-chemistry, and medical science. Attempts have been made in the present work to synthesize copper complex of guanine in order to gain greater insight in the metal interaction with guanine, which could help to understand the role of metal ions and Nucleobases in the biological process. Not too much research work was carried out with metal-ligand complex in searching their electrochemical behavior.

Electrochemical techniques, based on electrochemical sensors, are the most versatile analytical tool to study the redox behavior and to diagnose electro-active species in the field of chemistry, biochemistry, pharmacy, food science [10], and environmental science. Electrochemical sensors [11] are mostly based on the redox behavior of the analytes, for example, gas molecules, ions, and drugs. Sensitivity to a wide range of chemical species has made electrochemical sensor an essential tool for analysis and monitoring of pollutants, medicine, narcotics, neurotransmitters, and so forth.

In this present work we are interested in investigating the electrochemical behavior of those complexes and their influence in our body system. Hence, the study, the redox behavior of guanine at GCE electrode and its complexation with $\mathrm{Cu}$, has been investigated in aqueous medium by using electrochemical methods. Cyclic voltammetric studies of copper (II) and its complex with guanine to reveal the redox behavior in aqueous environment. Thus a systematic approach with the mode of formation and structural relationship with properties of this new compound may be derived from such study.

\section{Experimental}

2.1. Materials. Analytical grade $\mathrm{CuSO}_{4} \cdot 5 \mathrm{H}_{2} \mathrm{O}$ was purchased from E. Merck, Germany. Guanine $\left(\mathrm{C}_{5} \mathrm{H}_{5} \mathrm{~N}_{5} \mathrm{O}\right)$ was purchased from China. Extra pure acetic acid (BDH, England) and phosphoric acid (BDH, England) were procured for buffer.

2.2. Measurements. $\mathrm{CuSO}_{4} \cdot 5 \mathrm{H}_{2} \mathrm{O}$ was dissolved in deionized water to prepare $0.5-2.0 \mathrm{mM}$ solutions. Guanine solutions were prepared in slightly acidic medium (dil. $\mathrm{HCl}$ ) upon warming. The sodium acetate buffer solution was prepared by taking $0.1 \mathrm{M} \mathrm{CH}_{3} \mathrm{COONa}$, and $0.1 \mathrm{M} \mathrm{CH}_{3} \mathrm{COOH}$ of solutions at different ratios. The phosphate buffer solution was prepared by mixing $0.1 \mathrm{M}$ di-sodium hydrogen phosphate, $0.1 \mathrm{M} \mathrm{HCl}$, and $0.1 \mathrm{M} \mathrm{NaOH}$ solutions in different ratios. Milli-Q deionized water used throughout the experiment.

GCE was polished with fine alumina powder of 0.3 and then 0.03 micron sized on a wet polishing lather surface. For doing so a part of the lather surface was made wet with deionized water and alumina powder was sprinkled over it. The GCE was then polished on this surface for about 10-20 minutes by pressing softly the electrode against the polishing surface. A shiny black mirror like electrode surface was then thoroughly washed with deionized water. Under computer controlled magnetic stirring, experimental solution was deaerated by purging for at least 10 minutes with 99.9977\% pure nitrogen gas before performing every experiment. Traces of dissolved oxygen gas were thus removed from the solution. Thus interference due to molecular oxygen dissolved in the solutions was eliminated from the Cyclic Voltammograms.

Three electrodes system consists of a GCE as the working electrode, $\mathrm{Ag} / \mathrm{AgCl}$ (satd. $\mathrm{KCl}$ ) as the reference electrode, and platinum wire as the counter electrode was used. Cyclic Voltammetric measurement was performed using Computerized Electrochemical System, Model HQ-2040 developed by Advanced Analytics, USA. 


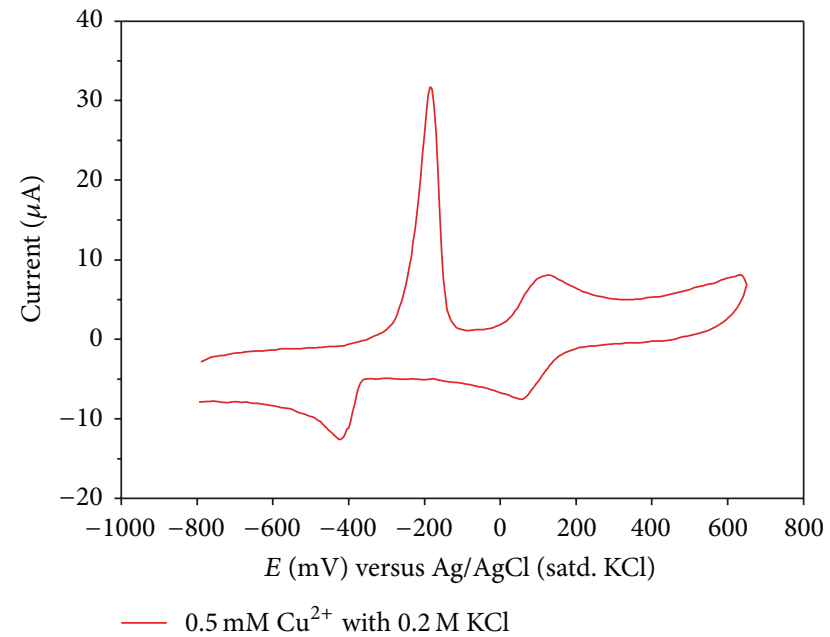

Figure 1: Cyclic Voltammogram of $0.5 \mathrm{mM} \mathrm{Cu}^{2+}$ in presence of $0.2 \mathrm{M} \mathrm{KCl}$ at $-800 \mathrm{mV}$ to $650 \mathrm{mV}$ potential window, $5 \mathrm{mV}$ step height and $100 \mathrm{mV} \mathrm{s}^{-1}$ scan rate.

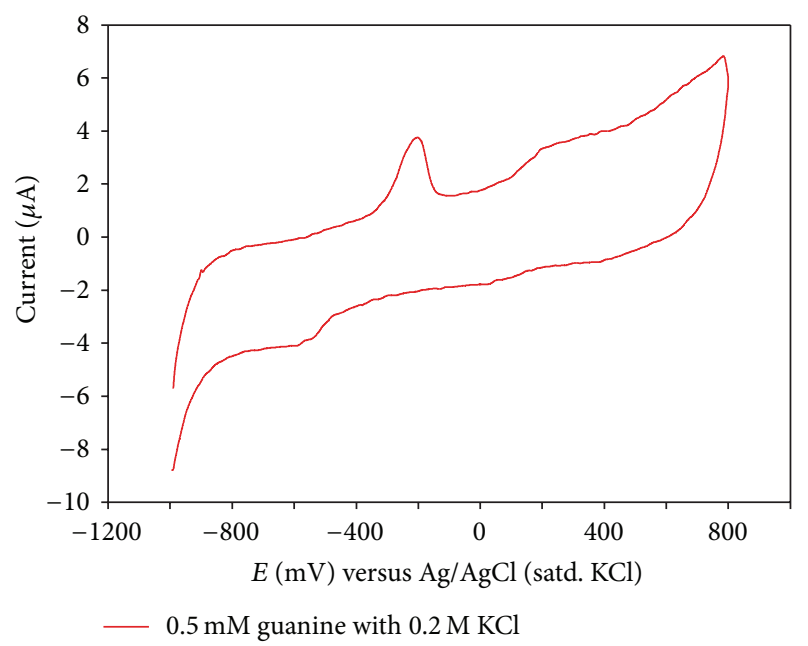

Figure 2: Cyclic Voltammogram of $0.5 \mathrm{mM}$ guanine in presence of $0.2 \mathrm{M} \mathrm{KCl}$ at $-1000 \mathrm{mV}$ to $800 \mathrm{mV}$ potential window, $5 \mathrm{mV}$ step height and $100 \mathrm{mV} \mathrm{s}^{-1}$ scan rate.

\section{Results and Discussion}

The redox behavior of $\mathrm{Cu}$ (II) in copper (II) sulphate was examined in $0.2 \mathrm{M} \mathrm{KCl}$ by Cyclic Voltammetric technique on glassy carbon electrode at room temperature.

From Figure 1 it is observed that $\mathrm{Cu}^{2+}$ solution is electroactive as it gives two cathodic and two anodic peaks. First anodic peak current is $8.0760 \mu \mathrm{A}$ and potential is $125 \mathrm{mV}$. Second anodic peak current is $31.7697 \mu \mathrm{A}$ and potential is $-185 \mathrm{mV}$. First cathodic peak current is $7.55 \mu \mathrm{A}$ and potential is $55 \mathrm{mV}$. Second cathodic peak current is $12.60 \mu \mathrm{A}$ and potential is $-425 \mathrm{mV}$. This implies that the $\mathrm{Cu}^{2+}$ system is a two electron reversible system.

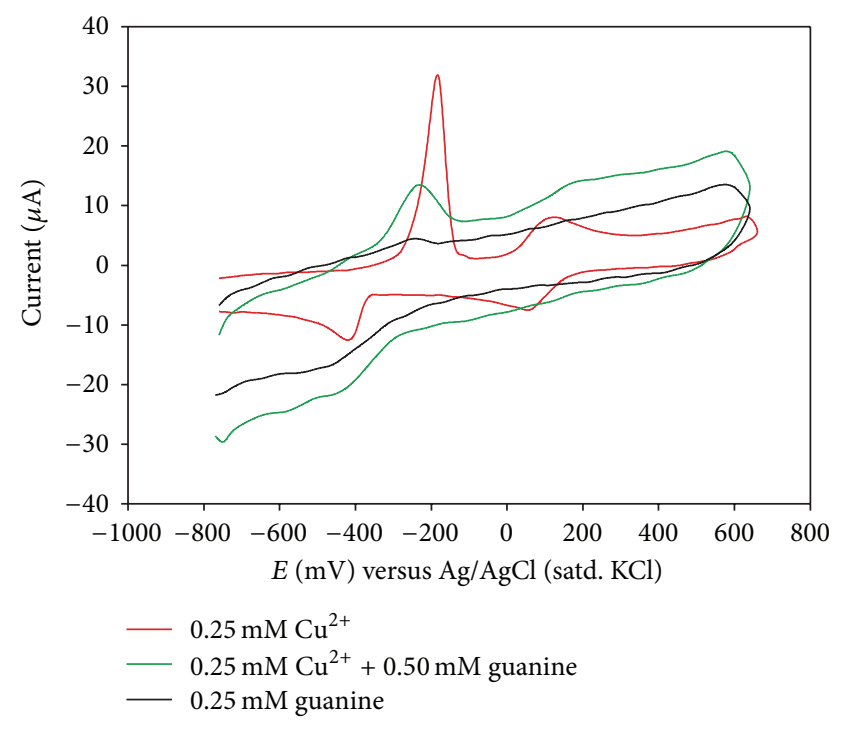

FIGURE 3: Cyclic Voltammograms of copper ion, copper-guanine complex and guanine in presence of $0.2 \mathrm{M} \mathrm{KCl}$.

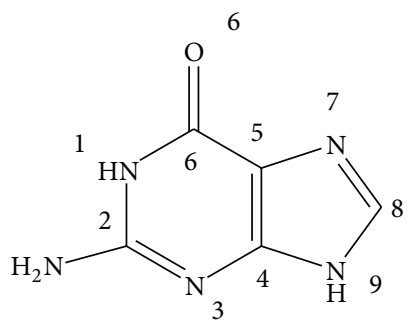

(a)<smiles></smiles>

(b)
Scheme 2: Structure of guanine: (a) non-protonated, (b) protonated.

3.1. Characterization of Copper-Guanine Complex. Cyclic Voltammogram of $0.5 \mathrm{mM}$ guanine, in presence of $0.2 \mathrm{M} \mathrm{KCl}$ at $-1000 \mathrm{mV}$ to $800 \mathrm{mV}$ potential window, $5 \mathrm{mV}$ step height and $100 \mathrm{mVs}^{-1}$ scan rate was taken.

From Figure 2 it is observed that it has an anodic peak at $-200 \mathrm{mV}$ potential having peak current of $3.7511 \mu \mathrm{A}$. It proves that guanine is an electroactive compound and an irreversible system [12]. The complexation ratio of copper-guanine is $1: 2$, confirmed by Jobs Continuous Variation Method and Mole Ratio Method.

3.1.1. Proposed Structure of the Copper-Guanine Complex. In Figure 3 a comparison has been depicted to understand the behavior of changing peak current.

Figure 3 illustrates that due to complex formation, peak current of copper ion decreases while that of guanine increases.

In acidic medium, ring nitrogen $\mathrm{N}(3)$ of guanine is protonated (Scheme 2).

The guanine complexes of several metal ions, such as $\mathrm{Al}(\mathrm{III}), \mathrm{Co}(\mathrm{II}), \mathrm{Cu}(\mathrm{II}), \mathrm{Zn}(\mathrm{II}), \mathrm{Pt}(\mathrm{II})$, and $\mathrm{Pd}(\mathrm{II})$ have been reported earlier $[13,14]$. It is found from the literature $[15,16]$ 
<smiles>[Y]n1cnc2nc(N)[nH]c(=O)c21</smiles>

$\left[\left(\mathrm{C}_{5} \mathrm{H}_{4} \mathrm{~N}_{5} \mathrm{O}\right)_{2} \mathrm{Cu}\right]$

Scheme 3: Proposed structure of copper (II) and guanine complex.

that guanine binds with metal ions through carbonyl oxygen $\mathrm{O}(6)$ and/or imidazolyl nitrogen, N(7). Early transition metal ions show a preference for the $\mathrm{O}(6)$ position, while later ones prefer $\mathrm{N}(7)$. However, the information available in this regard is very limited to understand the potential binding sites of guanine and the possible mechanism of interaction between guanine and the various metal ions.

Attempts have been made to obtain the complex in solid form for further structural analysis but due to the instable nature of the complex as the individual components precipitate out with increasing $\mathrm{pH}$, it was not possible to accumulate more structural analysis data to confirm the structure of the complex.

However from our observations and literature review Scheme 3 could be proposed as the structure of copper (II) and guanine complex $[17,18]$.

3.1.2. Variation of $\mathrm{Cu}^{2+}$ Concentration. Cyclic Voltammogram of $0.25 \mathrm{mM}$ guanine at $-800 \mathrm{mV}$ to $650 \mathrm{mV}$ potential window and $20 \mathrm{mV}$ step height and $100 \mathrm{mV} \mathrm{s}^{-1}$ scan rate in presence of $0.2 \mathrm{M} \mathrm{KCl}$ as supporting electrolyte and different $\mathrm{Cu}^{2+}$ ion concentrations $(0.25 \mathrm{mM}, 0.50 \mathrm{mM}, 0.75 \mathrm{mM}$, $1.00 \mathrm{mM}$, and $1.25 \mathrm{mM}$ ) reflects that as the concentration of the $\mathrm{Cu}^{2+}$ increases, more reactions take place [19] and more electrons are transferred so anodic and cathodic currents increase. As the complex is formed the anodic and cathodic potential shifts their position to more positive direction.

3.1.3. Variation of Guanine Concentration. Cyclic Voltammogram of $0.25 \mathrm{mM} \mathrm{Cu}^{2+}$ at $-800 \mathrm{mV}$ to $650 \mathrm{mV}$ potential window and $20 \mathrm{mV}$ step height and $100 \mathrm{mV} \mathrm{s}^{-1}$ scan rate in presence of $0.2 \mathrm{M} \mathrm{KCl}$ as supporting electrolyte and different guanine concentrations $(0.25 \mathrm{mM}, 0.50 \mathrm{mM}, 0.75 \mathrm{mM}$, $1.00 \mathrm{mM}$, and $1.25 \mathrm{mM}$ ) reflects that as the concentration of guanine increases the more reactions take place [20] and more electrons are transferred so anodic and cathodic current increase. As the complex is formed the anodic and cathodic potential shifts their position to more negative direction. As guanine is a least electroactive substance, the addition of guanine increases less amount of current compared to the addition of $\mathrm{Cu}^{2+}$ in guanine.

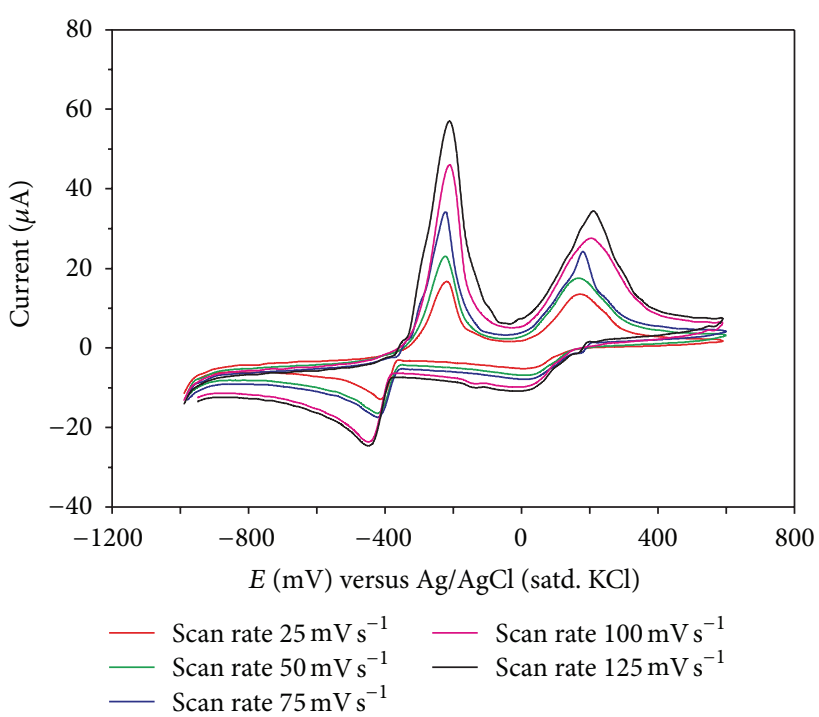

Figure 4: Cyclic Voltammogram of $0.6 \mathrm{mM} \mathrm{Cu}^{2+}$ and $1.2 \mathrm{mM}$ guanine at $-1000 \mathrm{mV}$ to $+600 \mathrm{mV}$ potential window and $20 \mathrm{mV}$ step height in presence of $0.2 \mathrm{M} \mathrm{KCl}$ as supporting electrolyte and different scan rates $\left(25,50,75,100\right.$, and $\left.125 \mathrm{mV} \mathrm{s}^{-1}\right)$.

3.1.4. Variation of Scan Rate. Cyclic Voltammogram of $0.6 \mathrm{mM} \mathrm{Cu}^{2+}$ and $1.2 \mathrm{mM}$ guanine at $-1000 \mathrm{mV}$ to $+600 \mathrm{mV}$ potential window and $20 \mathrm{mV}$ step height in presence of $0.2 \mathrm{M}$ $\mathrm{KCl}$ as supporting electrolyte and different scan rates $(25,50$, 75,100 , and $125 \mathrm{mV} \mathrm{s}^{-1}$ ) was taken (Figure 4).

The intensity for both the anodic and cathodic peaks is controlled by the following equation:

$$
i_{p}=2.69 \times 10^{5} \cdot n^{3 / 2} \cdot A \cdot D^{1 / 2} \cdot C \cdot v^{1 / 2},
$$

where, $i_{p}=$ peak current in ampere, $n=$ electron stoichiometry, $A=$ area of the electrode in $\mathrm{cm}^{2}, D=$ diffusion coefficient in $\mathrm{cm}^{2} / \mathrm{s}, C=$ concentration of the species in $\mathrm{mol} / \mathrm{cm}^{3}$, and $v=$ scan rate in volts $/$ s.

Two plots of anodic peak current versus square root of the scan rate and cathodic peak current versus square root of the scan rate are shown in the Figure 5, which depict the comparison of their increasing and decreasing trend, respectively.

The electrochemical processes are diffusion controlled which can be explained from the graph of $i_{p}$ versus $v^{1 / 2}$ as shown in Figure 4. First anodic current increases from $13.58 \mu \mathrm{A}$ to $34.64 \mu \mathrm{A}$ and second anodic current increases from $16.43 \mu \mathrm{A}$ to $57.13 \mu \mathrm{A}$. First cathodic current increases from $4.27 \mu \mathrm{A}$ to $11.06 \mu \mathrm{A}$ and second cathodic current increases from $12.84 \mu \mathrm{A}$ to $24.26 \mu \mathrm{A}$. From Figure 4 it can be explained that as the scan rate of the complex mixtures increases, the corresponding current increases but anodic and cathodic potential shift very little [21,22].

3.1.5. Variation of Step Height. Cyclic Voltammogram of $0.25 \mathrm{mM} \mathrm{Cu}^{2+}$ and $0.50 \mathrm{mM}$ guanine at $-800 \mathrm{mV}$ to $+600 \mathrm{mV}$ potential window at $100 \mathrm{mV} / \mathrm{S}$ scan rate at different step height $(20,25,30,35$, and $40 \mathrm{mV})$ was taken. It is observed 


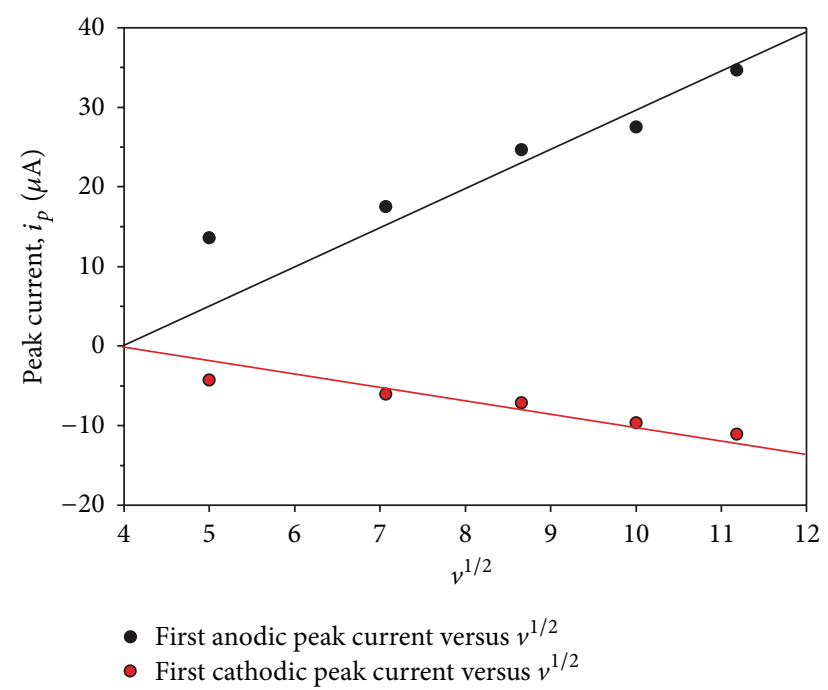

FIGURE 5: Peak current versus square root of the scan rate for copper and guanine complex.

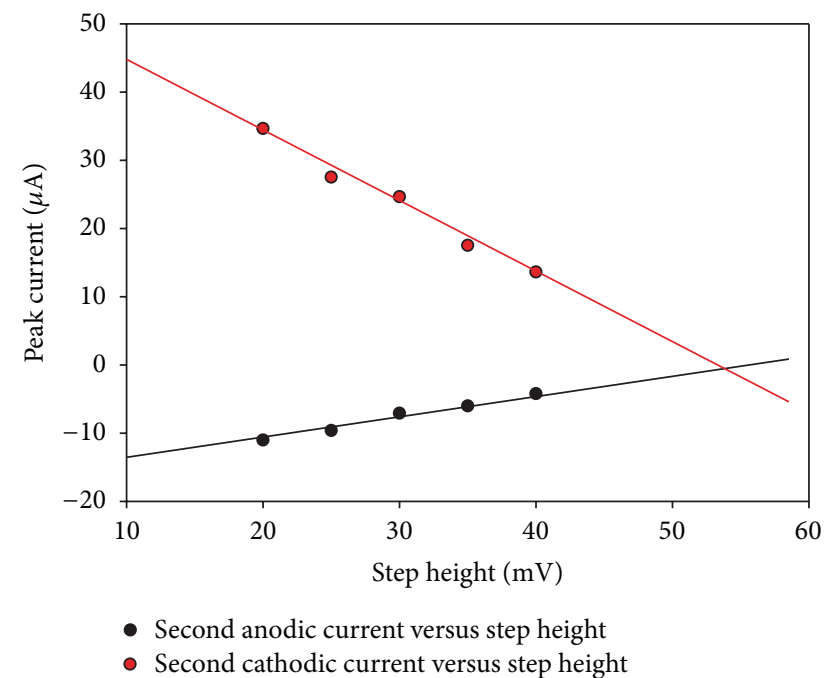

FIgure 6: Peak current versus step height for $\mathrm{Cu}^{2+}$ and guanine Complex.

as the anodic and cathodic current decreases linearly with increasing step height.

Moreover in the lower step height the peak becomes sharper. This might happen as the interaction between the metal ions and ligand ions decreases with increasing step height and complex formation decrease and consequently anodic and cathodic current decreases with increasing step height [23].

Plotting peak current versus step height Figure 6 is obtained, and it shows a straight line with negative slope, which indicates that the increase in step height decreases the peak current.

3.1.6. Variation of $p H$. Cyclic Voltammogram of $0.25 \mathrm{mM}$ $\mathrm{Cu}^{2+}$ and $0.50 \mathrm{mM}$ guanine at $-800 \mathrm{mV}$ to $+600 \mathrm{mV}$ potential

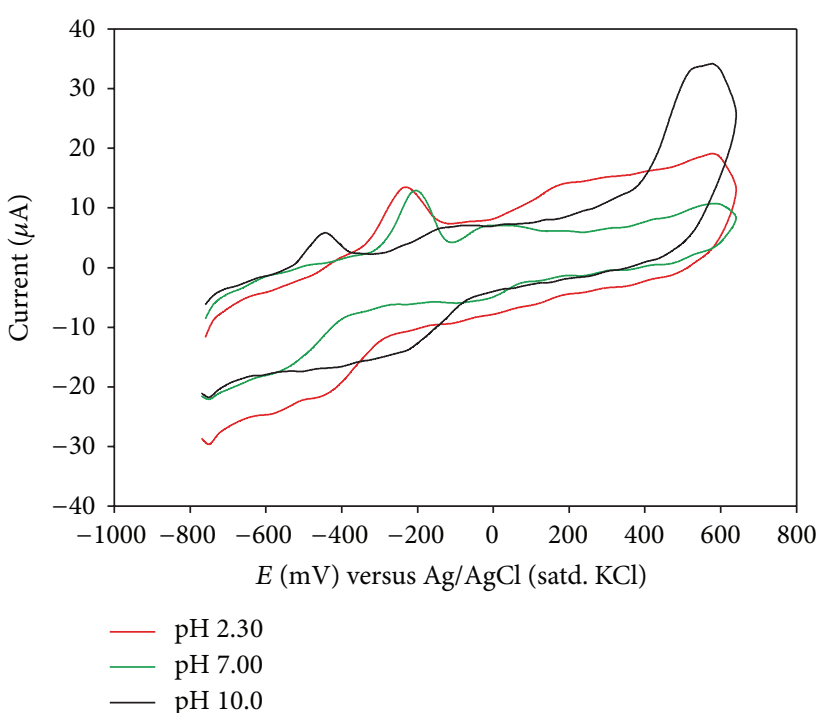

Figure 7: Cyclic Voltammogram of $0.25 \mathrm{mM} \mathrm{Cu}{ }^{2+}$ and $0.50 \mathrm{mM}$ guanine at $-800 \mathrm{mV}$ to $+600 \mathrm{mV}$ potential window at $100 \mathrm{mV} / \mathrm{S}$ scan rate and $20 \mathrm{mV}$ step height at different $\mathrm{pH}$ Values (2.30, 7.00, and $10.0)$.

window at $100 \mathrm{mV} / \mathrm{S}$ scan rate and $20 \mathrm{mV}$ step height at different $\mathrm{pH}$ Values $(2.30,7.00$, and 10.0) was taken (Figure 7) to see the effect of $\mathrm{pH}$ on the complex. At lower $\mathrm{pH}$ the $\mathrm{H}^{+}$ion can compete with $\mathrm{Cu}^{2+}$ ion for ligand in solution. But an increase in $\mathrm{pH}$ value will reduce the concentration of hydrogen ions which allows greater complex formation between $\mathrm{Cu}^{2+}$ and guanine. There was a little increase in peak current of $\mathrm{Cu}^{2+}$ guanine complex species below $\mathrm{pH}$ 7.0. From $\mathrm{pH} 7.0$ onwards, the peak current increased sharply, the optimum $\mathrm{pH}$ range appears to be between $\mathrm{pH} 2.3$ and 7.0.

3.1.7. Variation of Supporting Electrolyte. Figure 8 illustrates the effect of variation of supporting electrolyte on the electrochemical behavior of copper complexation with guanine.

Any species that compete with metal ion for the surface of the electrode would inevitably interfere in the adsorption of metal thyminate complex species hence leading to a decrease in the increase in current effect [24]. This explains why the supporting electrolyte such as $\left(\mathrm{NH}_{4}\right)_{2} \mathrm{SO}_{4}$, which is weakly complexing, produce higher current as compared to $\mathrm{NaCl}$ and $\mathrm{KCl}$. More over in case of $\mathrm{NaCl}$ and $\mathrm{KCl}$ both are Chloride containing Supporting electrolyte but $\mathrm{NaCl}$ is weakly complexing compared to $\mathrm{KCl}$ produces more current in the anodic and cathodic peak. So the order of the anodic and cathodic current enlargement is $\left(\mathrm{NH}_{4}\right)_{2} \mathrm{SO}_{4}>\mathrm{NaCl}>$ $\mathrm{KCl}$.

\section{Conclusions}

The results indicated that guanine is electroactive at $-1000 \mathrm{mV}$ to $800 \mathrm{mV}$ potential window and $100 \mathrm{mV} \mathrm{s}^{-1}$ scan rate as it has an anodic peak at $-200 \mathrm{mV}$ potential having peak current of $3.7511 \mu \mathrm{A}$ in the Cyclic Voltammogram. Cu 


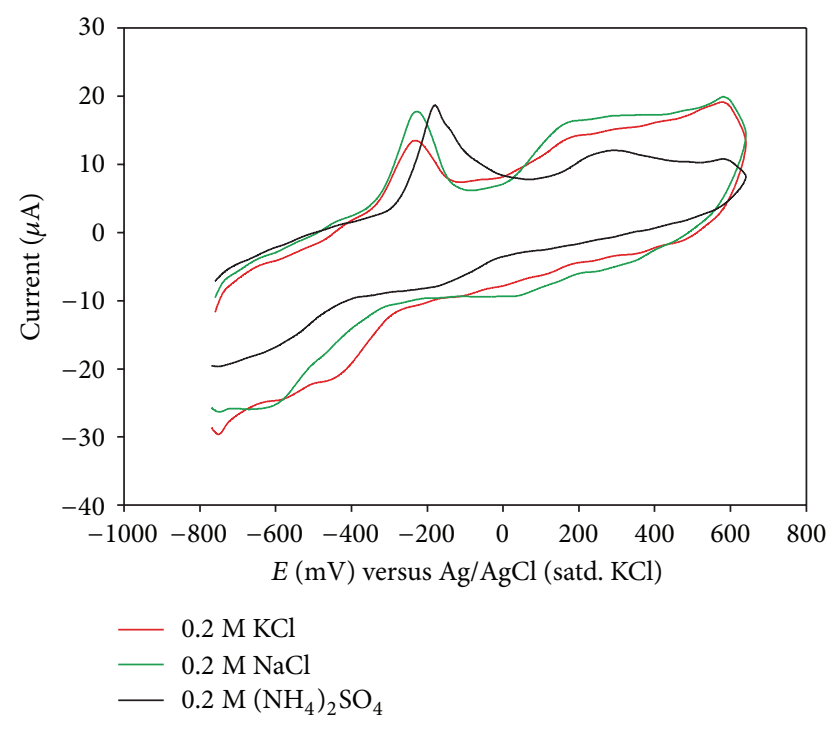

Figure 8: Cyclic Voltammogram of $0.25 \mathrm{mM} \mathrm{Cu}^{2+}$ and $0.50 \mathrm{mM}$ guanine at $-800 \mathrm{mV}$ to $+600 \mathrm{mV}$ potential window at $100 \mathrm{mV} / \mathrm{S}$ scan rate and $20 \mathrm{mV}$ step height in presence of different Supporting electrolytes $\left(0.2 \mathrm{M} \mathrm{KCl}, 0.2 \mathrm{M} \mathrm{NaCl}\right.$, and $\left.0.2 \mathrm{M}\left(\mathrm{NH}_{4}\right)_{2} \mathrm{SO}_{4}\right)$.

(II) is electroactive as it gives two cathodic and two anodic peaks. Two anodic peaks are at $125 \mathrm{mV}$ and $-185 \mathrm{mV}$ and two cathodic peaks at $55 \mathrm{mV}$ and $-425 \mathrm{mV}$ which indicate that $\mathrm{Cu}$ (II) is two electron processes.

Complex formation of metal ion and ligands were observed according to Jobs Method and Mole Ratio Method. $\mathrm{Cu}$ (II) forms 1:2 complexes with guanine. Probable structures of the complexes of copper with guanine have been proposed, which is being supported by the previous works.

As the concentration of any component increases, interaction between the metal and ligand increases, more complexes are formed, more electrons are transferred, and consequently current increases. Scan rate was varied for all the metal and ligand pairs which indicates the increase in scan rate increases the number of time of current scanning in the system per second increases. Hence the corresponding current also increases. Plot of the peak current versus square root of scan rate gives straight line with positive slope passing through origins which indicate that the peak current is directly proportional to the square root of the scan rate.

Step height was varied from $20 \mathrm{mV}$ to $40 \mathrm{mV}$ for copper and guanine complex which implies that the corresponding anodic and cathodic current decreases with increasing step height, it is due to less interaction between the metal and ligand ions and fewer complexes are formed.

The $\mathrm{pH}$ value of the complex mixture was varied from 2.3 to 10.0 for all metal and ligand complex mixture by using acetate and phosphate buffers. At a lower $\mathrm{pH}$ the $\mathrm{H}^{+}$ion compete with metal ions and less complexes are formed, less current is obtained, increasing $\mathrm{pH}$ value from 2.3 to 10.0 , and current increases and becomes maximum and then decreases rapidly with increasing $\mathrm{pH}$ value. That implies the complex is favored to slightly acidic medium and slightly alkaline medium. The optimum $\mathrm{pH}$ range can be considered as 2.3 to 7.0 for the complexes of copper with guanine and thymine.

The supporting electrolytes were used as $\left(\mathrm{NH}_{4}\right)_{2} \mathrm{SO}_{4}$, $\mathrm{NaCl}$, and $\mathrm{KCl}$ for all metal and ligand pair complex ratio. More interaction occurs when $\mathrm{SO}_{4}^{2-}$ containing supporting electrolyte $\left(\mathrm{NH}_{4}\right)_{2} \mathrm{SO}_{4}$ is used compared to chloride containing supporting electrolyte $\mathrm{KCl}$ and $\mathrm{NaCl}$. As $\mathrm{Na}$ is below $\mathrm{K}$ in the electrochemical series has higher tendency to be reduced compared to $\mathrm{K}$, so less current is found for $\mathrm{KCl}$ than $\mathrm{NaCl}$. So the complexation tendency of the supporting electrolytes follows the decreasing order $\left(\mathrm{NH}_{4}\right)_{2} \mathrm{SO}_{4}>\mathrm{NaCl}>\mathrm{KCl}$.

\section{Conflict of Interests}

The authors declare that there is no conflict of interests regarding the publication of this paper.

\section{References}

[1] N. Farrell, Transition Metal Complexes as Drugs and Chemotherapeutic Agents, vol. 11, Springer, 1989.

[2] U. C. Gupta and S. C. Gupta, "Trace element toxicity relationships to crop production and livestock and human health: implications for management," Communications in Soil Science and Plant Analysis, vol. 29, no. 11-14, pp. 1491-1522, 1998.

[3] B. A. Chowdhury and R. K. Chandra, "Biological and health implications of toxic heavy metal and essential trace element interactions," Progress in Food \& Nutrition Science, vol. 11, no. 1, pp. 57-113, 1987.

[4] V. Mudgal, N. Madaan, A. Mudgal, R. B. Singh, and S. Mishra, "Effect of toxic metals on human health," The Open Nutraceuticals Journal, vol. 3, pp. 94-99, 2010.

[5] J. O. Nriagu, "A silent epidemic of environmental metal poisoning?” Environmental Pollution, vol. 50, no. 1-2, pp. 139-161, 1988.

[6] J. N. Galloway, J. D. Thornton, S. A. Norton, H. L. Volchok, and R. A. N. McLean, "Trace-metals in atmospheric deposition: a review and assessment," Atmospheric Environment, vol. 16, no. 7, pp. 1677-1700, 1982.

[7] W. Zheng, M. Aschner, and J.-F. Ghersi-Egea, "Brain barrier systems: a new frontier in metal neurotoxicological research," Toxicology and Applied Pharmacology, vol. 192, no. 1, pp. 1-11, 2003.

[8] H. V. Aposhian, R. M. Maiorino, D. Gonzalez-Ramirez et al., "Mobilization of heavy metals by newer, therapeutically useful chelating agents," Toxicology, vol. 97, no. 1-3, pp. 23-38, 1995.

[9] S. J. S. Flora, M. Mittal, and A. Mehta, "Heavy metal induced oxidative stress \& its possible reversal by chelation therapy," Indian Journal of Medical Research, vol. 128, no. 4, pp. 501-523, 2008.

[10] M. Elyasi, M. A. Khalilzadeh, and H. Karimi-Maleh, "High sensitive voltammetric sensor based on Pt/CNTs nanocomposite modified ionic liquid carbon paste electrode for determination of Sudan I in food samples," Food Chemistry, vol. 141, no. 4, pp. 4311-4317, 1996.

[11] H. Karimi-Maleh, P. Biparva, and M. Hatami, "A novel modified carbon paste electrode based on $\mathrm{NiO} / \mathrm{CNT}$ s nanocomposite and (9, 10-dihydro-9, 10-ethanoanthracene-11, 12-dicarboximido)4-ethylbenzene-1, 2-diol as a mediator for simultaneous determination of cysteamine, nicotinamide adenine dinucleotide and folic acid," Biosensors and Bioelectronics, vol. 48, pp. 270275, 2013. 
[12] A. M. Oliveira-Brett, V. Diculescu, and J. A. P. Piedade, "Electrochemical oxidation mechanism of guanine and adenine using a glassy carbon microelectrode," Bioelectrochemistry, vol. 55, no. 1-2, pp. 61-62, 2002.

[13] A. A. Shaikh, K. Dilip Paul, M. S. Rahman, and K. Pradip Bakshi, "Interactions of guanine with $\mathrm{Cr}(\mathrm{VI}), \mathrm{Ag}(\mathrm{I}), \mathrm{Cd}(\mathrm{II})$ and $\mathrm{Hg}(\mathrm{II})$ in acidic aqueous medium," Journal of Bangladesh Chemical Society, vol. 24, no. 2, pp. 106-114, 2011.

[14] P. Kamalakannan and D. Venkappayya, "Synthesis and characterization of cobalt and nickel chelates of 5-dimethylaminomethyl-2-thiouracil and their evaluation as antimicrobial and anticancer agents," Journal of Inorganic Biochemistry, vol. 90, no. 1-2, pp. 22-37, 2002.

[15] A. Robertazzi and J. A. Platts, "Binding of transition metal complexes to guanine and guanine-cytosine: Hydrogen bonding and covalent effects," Journal of Biological Inorganic Chemistry, vol. 10, no. 8, pp. 854-866, 2005.

[16] S. Zhu, A. Matilla, J. M. Tercero, V. Vijayaragavan, and J. A. Walmsley, "Binding of palladium(II) complexes to guanine, guanosine or guanosine $5^{\prime}$-monophosphate in aqueous solution: potentiometric and NMR studies," Inorganica Chimica Acta, vol. 357, no. 2, pp. 411-420, 2004.

[17] T. F. Mastropietro, D. Armentano, E. Grisolia et al., "Guaninecontaining copper(ii) complexes: synthesis, X-ray structures and magnetic properties," Dalton Transactions, vol. 8, no. 4, pp. 514-520, 2008.

[18] E. Sletten and B. Lie, "Copper complex of guanosine- $5^{\prime}$ monophosphate," Acta Crystallographica, vol. 32, pp. 3301-3304, 1976.

[19] A. Habib, T. Shireen, A. Islam, N. Begum, and A. M. Shafiqul Alam, "Cyclic voltammetric studies of copper and manganese in the presence of L-leucine using glassy carbon electrode," Pakistan Journal of Analytical \& Environmental Chemistry, vol. 7, pp. 96-102, 2006.

[20] A. A. Abdullah, "Synthesis and structural studies of some nucleic acids metal complexes," Basrah Journal of Scienec, vol. 24, no. 1, pp. 115-128, 2006.

[21] R. B. Sumathi and M. B. Halli, "Metal (II) complexes derived from naphthofuran-2-carbohydrazide and diacetylmonoxime Schiff base: synthesis, spectroscopic, electrochemical, and biological investigation," Bioinorganic Chemistry and Applications, vol. 2014, Article ID 942162, 11 pages, 2014.

[22] T. Al Tanvir, M. Elius Hossain, M. Al Mamun, and M. Q. Ehsan, "Preparation and characterization of Iron(Iii) complex of Saccharin," Journal of Bangladesh Academy of Sciences, vol. 37, no. 2, pp. 195-203, 2013.

[23] I. Cukrowski, J. R. Zeevaart, and N. V. Jarvis, "A potentiometric and differential pulse polarographic study of $\mathrm{Cd}(\mathrm{II})$ with 1hydroxyethylenediphosphonic acid," Analytica Chimica Acta, vol. 379, no. 1-2, pp. 217-226, 1999.

[24] A. A. Shaikh, M. Badrunnessa, J. Firdaws, M. Shahidur Rahman, N. Ahmed Pasha, and P. K. Bakshi, "A cyclic voltammetric study of the influence of supporting electrolytes on the redox behaviour of $\mathrm{Cu}$ (II) in aqueous medium," Journal of Bangladesh Chemical Society, vol. 24, no. 2, pp. 158-164, 2011. 

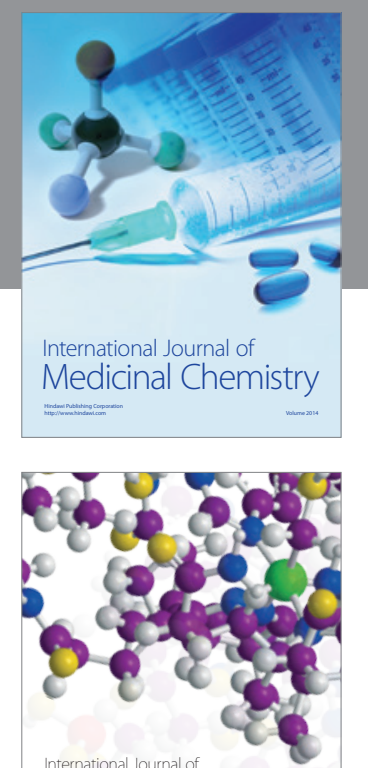

\section{Carbohydrate} Chemistry

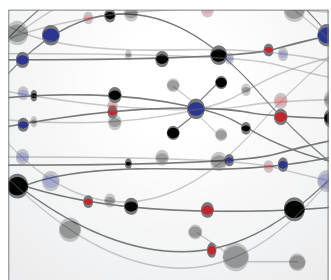

The Scientific World Journal
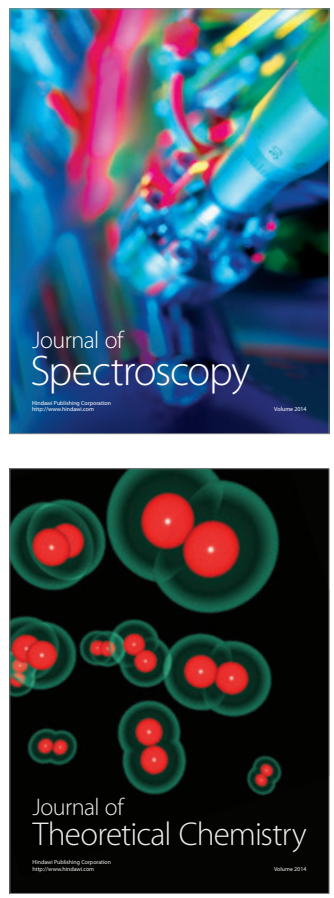
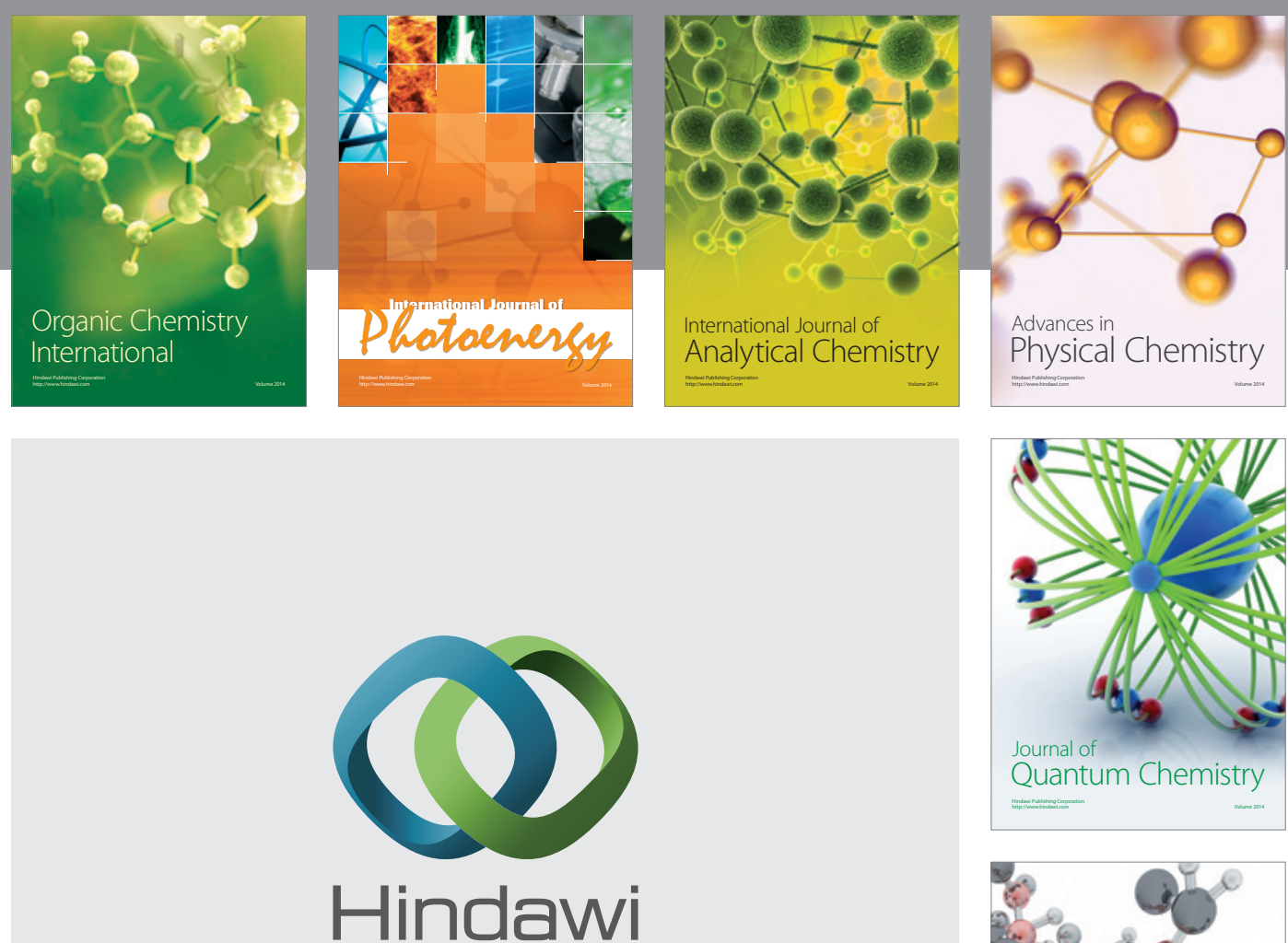

Submit your manuscripts at

http://www.hindawi.com

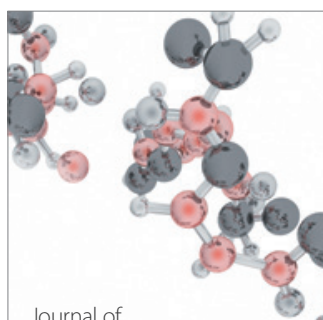

Analytical Methods

in Chemistry

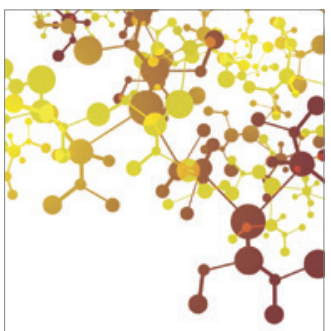

Journal of

Applied Chemistry

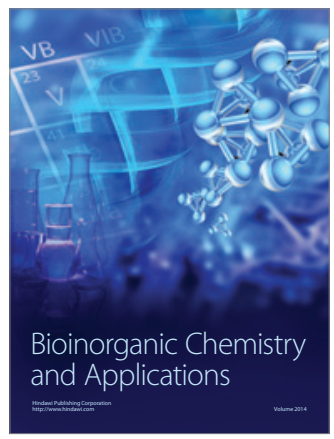

Inorganic Chemistry
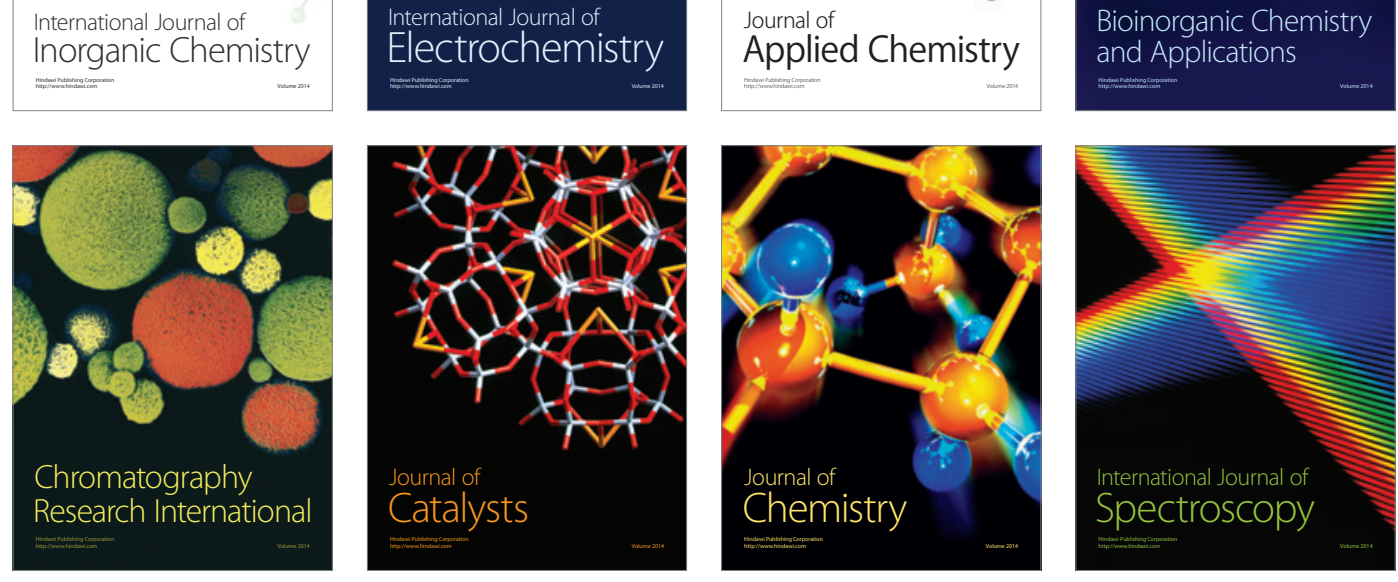